\title{
Firm's Commitment And Brand Image And Their Impact On Experience Marketing: Developing Country's Perspective
}

Muhammad Sabbir Rahman; Multimedia University, Malaysia

Abdul Highe Khan; International Islamic University Malaysia, Malaysia

Hasan Moudud, International Islamic University Malaysia, Malaysia

\begin{abstract}
This research applied exploratory factor analysis, confirmatory factor analysis and structural equation modeling to investigate the experience marketing philosophy on service providers within the context of Bangladeshi consumers'. The findings confirmed that there is a strong relationship between brand images towards experience marketing when physical context of a firm plays a mediating role. This research opens up opportunities for managers to identify significant factors those are linked towards building experience marketing.
\end{abstract}

Keywords: Firms Commitment; Brand Image; Customers' Satisfaction; Physical Context; Service Industries

\section{INTRODUCTION}

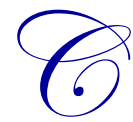

ustomer-employee interaction is essential for any service or product-based firm. Indeed, no systematic review of the literature on the concept of experience marketing has yet been published under a developing country's consumers' perspective (Mitchell, 1998; Pine and Gilmore, 1997). This study not only revealed the significant factors of experience marketing but also it provides a greater degree of guidelines for academicians and managers in developing better marketing strategies for the service oriented companies in Bangladesh.

\section{REVIEW OF LITERATURE}

Experience can be an individual, a community, a nation, or even humankind as a whole that can be defined as a new idea that changes the way marketers think about their brands (Mitchell, 1998; Helkkula, 2010). Pine and Gilmore (1997) argued that goods and services were no longer enough to compete in today's increasingly commoditized world and companies had to move beyond goods and services to stage experiences and guide transformations. In other research they also applied the theme of experience economy in different industry (Pine and Gilmore, 2001; Williams, 2006, Rahman et al. 2012).

\section{Firm's Commitment and Experience Marketing}

Commitment is a valued relationship with maximum effort being expanded and as a result there will be sustainable forward-looking by both party in future (Morgan and Hunt 1994; Gustafsson et al. 2005). In marketing literature, commitment has two distinct natures; affective and calculative. Effective commitment focuses on psychological attachment to a service provider and calculative commitment emphasizes on switching costs (Gundlach et al. 1995; Bansal et al. 2004). A significant amount of literature suggested that a firm's commitment has a huge effect on building experience marketing in various ways (Brown et al. 2005; Verhoef et al. 2002; Fullerton, 2005). Thus, based on the above literature it is hypothesized that:

H1: There is a strong relationship between a firm's commitments towards implementation of experience marketing where customer's satisfaction play as a mediating role. 


\section{Brand Image and Experience Marketing}

The brand associations (value-proposition; emotional or self -expressive) can be tangible or emotional or symbolic or both (Hulten, 2009; Anselm and Kostelijk, 2008; Ratneshwar and Mick, 2005). According to Hulten (2009), from emotional perspective, most of the enterprises are focusing more on tangibles. This includes the physical and relational characteristics (Gupta and Vajic, 1999). In the physical context example of stimulators are created by the sights, sounds, textures, and smells of the environment and, in the relational context, stimulators emanate from people and their behavior (Carbone and Haeckel, 1994).Even though in brand and customers experience context little attention has been given to understand the creation of a brand as an image (Payne et al. 2009). Thus based on the above literature it is hypothesized that:

H2: There is a strong relationship between brand images towards implementation of experience marketing where enhancement of physical context play as a mediating role.

\section{Conceptual Framework:}

The entire research rests on the basis of the theoretical framework. Based on the previous literature reviews; this research concentrates on conceptual framework of factors that help. The detailed diagram framework is given below through Figure 1.1:

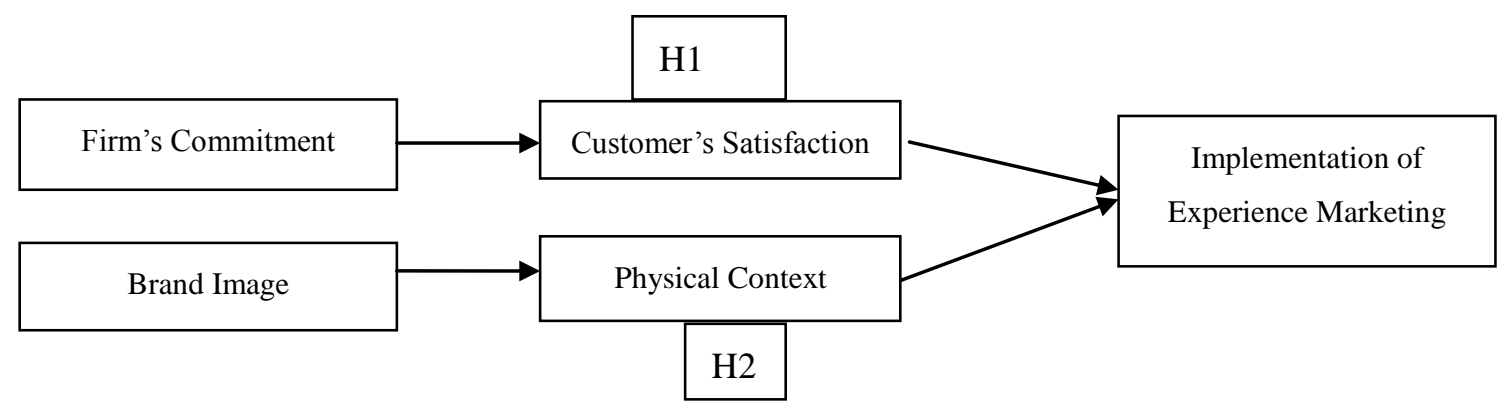

Figure 1.1: Conceptual Framework

\section{METHODOLOGY}

To accomplish research objective, this study employed a four-step methodology. First, from a review various scholars' articles, this research generated 24 items in fact each variable consisted with five items that were measured with each latent variable (Firm's Commitment; Brand Image; Customer's Satisfaction; Physical Context; Experience Marketing). This research were employed a survey via convenient sampling procedure by using shopping mall intercept at significant places in Dhaka. A total of 300 individuals responded response were collected through the mall intercept under the category of consumer of electronics, hairdressing and beauty salons, restaurants consumers'.

\section{Data Analysis Procedure}

The data analysis of this study was organized into four stages, as shown in using the descriptive and inferential statistics techniques. The first stage of the data analysis used means, frequency, and percentages to represent the respondent's overall demographic profile. The second stage of the data analysis used the exploratory factor analysis (EFA) to identify the factor structure and check the validity and the reliability of the scale. In the third phase of the data analysis, this research employed confirmatory factor analysis (Gerbing and Anderson, 1988) and structural equation modeling to test the hypothesis. This research used chi-square statistic/degree of freedom as well as model fit indices such as comparative fit index, non-normed fit index, and root-mean-square residual were examined to evaluate the adequate fit of models (Bentler, 1990; Bentler and Bonett, 1980; Tucker and Lewis, 1983; Nevitt and Hancock, 2000). 


\section{RESEARCH RESULTS}

\section{Descriptive Analysis Results of Survey and Respondent's Profile}

Among the 300 respondents, 50 did not fill out the questionnaires completely. This result yielded 250 usable questionnaires which resulted in an $85 \%$ adjusted response rate. Among the 250 respondents there were more male respondents $(60.0 \%)$ than female respondents $(40.0 \%)$. The majority of respondents were between 20 to 29 years old (70\%) and the second largest were between 30 to 39 years old $(25 \%)$. Most of the respondents worked at service-oriented company (50\%), whereas $30 \%$ of the respondents worked at manufacturing-oriented companies. In addition, 80 percent of the respondents reported that they cared for companies who deliver products with good experience whereas 20 percent of the respondents were not even aware about experience marketing.

\section{Exploratory Factor Analysis (EFA)}

To assess the validity and reliability of each construct, factor analysis and reliability testing were used. After factor analysis using the varimax rotation 16 items were kept for further analysis (Firm's Commitment-4; Brand Image -4; Customer's Satisfaction -4; Physical Context-4). To test the appropriateness of factor analysis, the Kaiser-Meyer-Olkin (KMO) overall measure of sampling adequacy (MSA) was calculated as 0.82 (Table 1) which is meritorious (Kaiser, 1974). In addition, the communalities range from 0.57 to 0.92 with an average value above 0.70 , suggesting that the variance of the original values were fairly explained by the common factors. Four stable factors were derived from the analysis (Table 1)

Table 1: Summary of Exploratory Factor Analysis

\begin{tabular}{|c|c|c|c|c|c|}
\hline Factor Name & EV1 & PV2 & CV3 & Component Variables & Factor Loading \\
\hline $\begin{array}{l}\text { Firm's Commitment } \\
\text { Chronbach Alpha = } \mathbf{. 7 4}\end{array}$ & 2.792 & 8.217 & 21.223 & $\begin{array}{l}\text { Affordable for middle income group } \\
\text { Financial access to purchase } \\
\text { Positive Feelings } \\
\text { Delivery of services }\end{array}$ & $\begin{array}{l}.779 \\
.771 \\
.666 \\
.671 \\
\end{array}$ \\
\hline $\begin{array}{l}\text { Brand Image } \\
\text { Chronbach Alpha = .83 }\end{array}$ & 1.693 & 7.600 & 29.013 & $\begin{array}{l}\text { Image building Program } \\
\text { Service dependably } \\
\text { Security and privacy } \\
\text { Customer acquisition } \\
\text { Promotion }\end{array}$ & $\begin{array}{l}.612 \\
.678 \\
.678 \\
.671\end{array}$ \\
\hline $\begin{array}{l}\text { Customers Satisfaction } \\
\text { Chronbach Alpha = .75 }\end{array}$ & 1.545 & 6.101 & 41.269 & $\begin{array}{l}\text { Ability of flexibility and dynamic } \\
\text { Community support } \\
\text { Location convenience } \\
\text { Priori expectations }\end{array}$ & $\begin{array}{l}.679 \\
.678 \\
.618 \\
.688 \\
\end{array}$ \\
\hline $\begin{array}{l}\text { Physical Context } \\
\text { Chronbach Alpha = .83 }\end{array}$ & 1.545 & 7.101 & 43.869 & $\begin{array}{l}\text { Technology intensity } \\
\text { Internal Atmosphere } \\
\text { Voice and music in the atmosphere } \\
\text { Exterior and interior design }\end{array}$ & $\begin{array}{l}.779 \\
.678 \\
.718 \\
.688\end{array}$ \\
\hline
\end{tabular}

Notes: 1: Eigenvalue (EV1) 2: Percent of Variance (PV2) 3: Cumulative Variance (CV3)

In this research, content validity deals with "how representative and comprehensive the items were in creating by the scale" (Bohrnstedt, 1970).This research assessed them by examining the process by which scale items were generated (Straub, 1989). In this study, definitions of the constructs were proposed based on the literature review. In the SEM (Structural Equation Method) method, construct validity was viewed as hypothesis testing in which specific relations were posited and tested which were applied in this study (Hancock and Freeman, 2001). In order to demonstrate convergent validity, items that measure the same trait should correlate highly with one another if they are valid measures of the concept. To make composite measures of the constructs, the summated mean scales were calculated in this research (Hair et al., 1998). 


\section{Confirmatory Factor Analysis and Structural Equation Modeling}

To confirm the factor, this research was conducted confirmatory factor analysis. Results from the CFA using AMOS software were summarized in Table 2. The fit indices demonstrated good fit of the measurement models to the data. The full model was tested based on the measurement model previously validated from CFA in the study. The fit indices of the full model were $\chi^{2} / \mathrm{df}=2.65\left(\chi^{2}=3577.133, \mathrm{df}=1348\right)$; GFI $=.921$; AGFI $=.915$; RMSEA $=.051 ; \mathrm{CFI}=.913 ; \mathrm{NFI}=.924$. To assess the mediating effects towards of experience marketing under the customers' perspective this research examined the predictive validity of the hypothesized model using decomposition of effects through Mplus. As predicted it was observed that there was a strong relationship between rand images towards implementation of experience marketing where enhancement of physical context played a mediating role supporting H2 (See Table: 2). The results also showed that there is a moderate relationship between firm's commitment towards experience marketing when customers' satisfactions play as a mediating role supporting nearly H3 (See Table 2).

Table 2: The estimates of the mentioned variable

\begin{tabular}{|c|c|c|c|c|c|}
\hline \multicolumn{2}{|c|}{ Path Direction } & $\begin{array}{c}\text { Estimates } \\
\text { (Estimate of } \\
\text { regression } \\
\text { weight) }\end{array}$ & $\begin{array}{c}\text { S.E(Standard } \\
\text { error of } \\
\text { regression } \\
\text { weight) } \\
\end{array}$ & $\begin{array}{c}\text { C.R (Critical } \\
\text { ratio for } \\
\text { regression } \\
\text { weight) }\end{array}$ & $\begin{array}{c}\text { P (Level of } \\
\text { significance } \\
\text { for regression } \\
\text { weight) }\end{array}$ \\
\hline Customers' satisfaction & $\longleftarrow$ Firms' Commitment & .395 & .070 & 7.364 & .003 \\
\hline Physical Context & $\leftarrow \quad$ Brand Image & .685 & .060 & 8.949 & .000 \\
\hline Experience marketing & $\longleftarrow$ Customers' Satisfaction & .280 & .043 & 6.269 & .002 \\
\hline Experience marketing & $\longleftarrow$ Physical Context & .485 & .043 & 3.701 & .000 \\
\hline
\end{tabular}

\section{CONCLUSIONS}

More precisely, the findings suggested that there is a strong relationship between brand images (BI) towards experience marketing (EM) when physical context of a firm (PC) plays a mediating role. Besides that, the result also confirms that a firm's commitment (FC) has moderate relationship with experience marketing (EM) when customer's satisfaction plays a mediating role. It is evident that staging experience can act as a source of core competency for a business in strengthening its brand recognition, building company image, and providing unique feature to the consumers in the bundle of offering. Managers are suggested to develop a more 'personal' and unique one-on-one connection with customers. The most significant limitations of this research are the cross-sectional and self-reported data. The use of such data may have led to the overestimation of the relationships. Secondly, this study took place within a specific geographic area (Dhaka city). As a result, the findings of this study may not be generalized to other countries. Future research should aim to obtain larger sample size in other countries to reach comparative results

\section{AUTHOR INFORMATION}

Muhammad Sabbir Rahman, Senior Lecturer, Graduate School of Management, Multimedia University, Persiaran Multimedia, 63100 Cyberjaya, Malaysia. E-mail: muhammad.sabbir@mmu.edu.my (Corresponding Author)

Abdul Highe Khan, Graduate Research Student, Faculty of Economics and Management Sciences, International Islamic University, Malaysia

Hasan Moudud, Graduate Research Student, Faculty of Economics and Management Sciences, International Islamic University, Malaysia

\section{REFERENCES}

1. Anselm, K.J. \& Kostelijk, E. (2008). Identity based marketing: A new balanced marketing paradigm. European Journal of Marketing, 42(9/10), 907-14. 
2. Bansal, H. S., Irving, P. G., \& Taylor, S. F. (2004). A Three-Component Model of Customer Commitment to Service Providers. Journal of the Academy of Marketing Science, 32(3), 234-250.

3. Bentler, P. M., \& Bonett, D. G. (1980). Significant tests and goodness of fit in the analysis of covariance structure. Psychological Bulletin, 88, 588-606.

4. Bentler, P.M. (1990). Comparative fit indexes in structural models, Psychological Bulletin, 107, 238-46.

5. Bohrnstedt, G.W. (1970). Reliability and Validity in Attitude Measurement. In G.F. Summers (Ed.) Attitude Measurement. Chicago: Rand McNally, 80-99.

6. Brown, T.J., Barry, T.E., Dacin, P.A. \& Gunst, R.F. (2005). Spreading the word: investigating antecedents of consumers' positive word-of-mouth intentions and behaviors in a retailing context, Journal of the Academy of Marketing Science, 33 (2), 123-38.

7. Carbone, L. \& Haeckel, S. (1994). Engineering customer experience, Marketing Management, 3 (3), 8-19.

8. Fullerton, G. (2005). How commitment both enables and undermines marketing relationships, European Journal of Marketing, 39 (11/12), 1372-88.

9. Gerbing, D. W \& Anderson, J. C. (1988). Structural Equation Modeling in Practice: A Review and Recommended Two-Step Approach. Psychological Bulletin, 103, (3), 411-423.

10. Gupta, S. \& Vajic, M. (1999). The contextual and dialectical nature of experiences, in Fitzsimmons, J. and Fitzsimmons, M. (Eds), New Service Development, Sage, Thousand Oaks, CA, 33-51.

11. Gustafsson, A., Johnson, M. \& Roos, I. (2005). The effects of customer satisfaction, relationship commitment dimensions, and triggers on customer retention, Journal of Marketing, 69 (4), 210-18.

12. Hair, J. F., Jr., Anderson, R. E., Tatham, R. L. \& Black, W. C. (1995). Multivariate Data Analysis, 3rd ed, Macmillan Publishing Company, New York.

13. Hair, J. F., Anderson, R. E., Tatham, R. L. \& Black, W. C. (1998a).Multivariate Data Analysis, (5th Ed.): Prentice Hall.

14. Hancock GR, Freeman MJ.(2001). Power and Sample Size for the Root Mean Square Error of Approximation Test of Not Close Fit in Structural Equation Modeling. Educational and Psychological Measurement., 61, 741-58.

15. Helkkula; A (2010). Characterising the concept of service experience. Journal of Service Management. 22 (3), 367-389.

16. Hoyle, R., \& Smith, G.T. (1994). Formulating clinical research hypotheses as structural equation models: A conceptual overview. Journal of Consulting and Clinical Psychology,.62(3), 429-440.

17. Kaiser, H.F. (1974). An index of factorial simplicity. Psychometrika, 39, 31-36.

18. Langeard, E., Bateson, J., Lovelock, C. \& Eiglier, P. (1981). Marketing of services: New insights from consumers and managers, Cambridge MA Marketing Sciences Institute.

19. Mitchell, A. (1998). What's the big idea of experience marketing?, Marketing Week, 21 (19), 28-9..

20. Morgan, R.M. and S.D. Hunt, (1994) . The commitment-trust theory of relationship marketing, Journal of Marketing, 58(3): 20-38.

21. Nevitt J \& Hancock G.R. (2000). Improving the root mean square error of approximation for nonnormal conditions in structural equation modeling. Journal of Experimental Education, 68:251-68.

22. Payne, A., Storbacka, K., Frow, P. \& Knox, S. (2009). Co-creating brands: diagnosing and designing the relationship experience, Journal of Business Research, 62, 379-89.

23. Pine \& Gilmore. (1997). Beyond goods and services: staging experiences and guiding transformations, Strategy \& Leadership, 25. (3), 234-50.

24. Pine \& Gilmore. (2001). Welcome to the experience economy, Health Forum Journal, 44, 10.

25. Rahman, M. S., Khan, A. H., Murtaza, M., Haque, M. M., Hussain, B. (2012). Experience as a Marketing Tools: A Distinct Thinking under Developing Country's Consumers' Perspective. Journal of Applied Sciences, 12: 2295-2303

26. Ratneshwar, S. \& Mick, D. (2005). Inside Consumption, Routledge, London.

27. Straub, (1989). Validating Instruments in MIS Research, MIS Quarterly, 13 (2), 147-169.

28. Tabachnick, B.G., \& Fidell, L.S. (2001). Using Multivariate Statistics (4th edn.). Boston: Allyn and Bacon.

29. Tucker, L.R. and Lewis, C. (1973). A reliability coefficient for maximum likelihood factor analysis, Psychometrika, 38, 1-10.

30. Verhoef, P.C., Franses, P.H. \& Hoekstra, J.C. (2002). The effect of relational constructs on customer referrals and number of services purchased from a multiservice provider: does age of relationship matter?, Journal of Academy of Marketing Science, 30(3), 202-16. 
31. Williams, A. (2006). Tourism and hospitality marketing: Fantasy, feeling and fun. International Journal of Contemporary Hospitality Management, 18(6/7), 482-495.

\section{NOTES}

